\title{
PFN1 Gene
}

National Cancer Institute

\section{Source}

National Cancer Institute. PFN1 Gene. NCI Thesaurus. Code C125444.

This gene plays a role in the regulation of actin polymerization. 